\title{
Clinical follow up of Mexican women with early onset of breast cancer and mutations in the BRCA1 and BRCA2 genes
}

\author{
Ana Laura Calderón-Garcidueñas, MD, MSc, ${ }^{(1,2)}$ Pablo Ruiz-Flores, MD, PhD, ${ }^{(3)}$ Ricardo M Cerda-Flores, PhD, (2) \\ Hugo A Barrera-Saldaña, PhD. ${ }^{(4)}$
}

\section{Calderón-Garcidueñas AL, Ruiz-Flores $P$, Cerda-Flores RM, Barrera-Saldaña HA. Clinical follow up of Mexican women with early onset of breast cancer and mutations in the BRCA1 and BRCA2 genes. Salud Publica Mex 2005;47:110-115.}

\begin{abstract}
A bstract
Objective. This study describes the presence of mutations in BRCA1 and BRCA2 genes in a group of Mexican women and the clinical evolution of early onset breast cancer (EO BC). Material and Methods A prospective hospital-based study was performed in a sample of 22 women with EO BC (7 in clinical stage IIA, 8 in IIB, and 7 in IIIA). The patients attended a tertiary care hospital in northeastern Mexico in 1997 and were followed up over a 5-year period. Molecular analysis included: 1) a mutation screening by heteroduplex analysis (HA) of BRCA 1 and BRCA2 genes and 2) a sequence analysis. Results. Of 22 patients, 14 (63.6\%) showed a variant band detected by heteroduplex analysis of the BRCA 1 and BRCA 2 genes: 8 polymorphisms, 4 mutations of uncertain significance, and 2 novel truncated protein mutations, one in BRCA1 (exon 11, 3587delT) and the other in the BRCA2 gene (exon 11, 2664InsA). Conclusions. These findings support future studies to determine the significance and impact of the genetic factor in this Mexican women population.
\end{abstract}

Key words: breast cancer; BRC A genes; Mexico

\author{
Calderón-GarcidueñasAL, Ruiz-Flores $\mathrm{P}$, \\ Cerda-Flores RM, Barrera-Saldaña HA. \\ Estudio de seguimiento clínico de mujeres mexicanas \\ con cáncer de mama de inicio temprano \\ y mutaciones en los genes BRCA1 y BRCA2. \\ Salud Publica Mex 2005;47:110-115.
}

\begin{abstract}
Resumen
Objetivo. Describir la presencia de mutaciones en los genes BRCA1 y BRCA2 y la evolución clínica de un grupo de mujeres con carcinoma mamario de inicio temprano (CMIT). Material y métodos Se realizó un estudio hospitalario, prospectivo, en una muestra de 22 pacientes con CMIT (siete en etapa clínica IIA, ocho en la IIB y siete en etapa IIIA). Las pacientes fueron atendidas en un hospital del noreste de México en 1997 y se realizó un seguimiento clínico durante cinco años. El análisis molecular incluyó: 1) análisis heterodúplex $(\mathrm{AH})$ para detectar bandas variantes en la secuencia de ADN de los genes BRCA1 y BRCA2, y 2) análisis de secuenciación. Resultados. De 22 pacientes, 14 (63.6\%) mostraron banda variante por AH en los genes BRCA1 y BRCA2: ocho polimorfismos, cuatro mutaciones de significado incierto y dos mutaciones noveles con proteína truncada, una en BRCA1 (exón 11,3587delT) y otra en BRCA2 (exón 11, 2664InsA). Conclusiones Estos hallazgos apoyan el desarrollo de futuros estudios para determinar el impacto del factor genético en la población mexicana con CMIT.
\end{abstract}

Palabras clave: cáncer de mama; genes, BRCA; México

W e express our gratitude to the PAICYT Program, the 0 ffice of the President of UAN L, the FO FO I:IMSS-2002/021/20111021 for funding, and Conacyt for the doctoral scholarship (93354) to ALCG. We also thank the PRO MEP program of the Federal Secretariat of Education and the Mexican N ational C ouncil of Science and Technology for support.

(1) Department of Pathology, Hospital de Especialidades N 0. 25, Instituto Mexicano del Seguro Social (IMSS), Monterrey, Nuevo León, México.

(2) Department of Population Genetics, N ortheastern Center for Biomedical Research, IMSS, Monterrey, N uevo León, México.

(3) Center for Biomedical Research, Department of Genetics, Medical School,Autonomous University of C oahuila. Torreón, C oahuila.

(4) Department of Biochemistry, Medical School, Universidad Autonóma de N uevo León. Monterrey, N uevo León, México.

Received on: N ovember 7,2003 - Accepted on: February 1,2005

Address reprint requests to: Prof. D r. Hugo A Barrera-Saldaña. Departamento de Bioquímica. Facultad de Medicina de la Universidad Autónoma de N uevo León. Avenida Madero y Dr. Eduardo Aguirre Pequeño, colonia Mitras Centro 64460, Monterrey, N uevo León, México. E-mail: hbarrera@fm.uanl.mx 
B reast cancer $(\mathrm{BC})$ has evolved as one of the main causes of morbidity and mortality for women. Each year, at least a million women are diagnosed with this disease in the world and the number of deaths is estimated in $300000 .{ }^{1}$ Annually, 180000 new cases and 30000 deaths are reported in the United States. ${ }^{2}$

Mexico is a country with almost 98 million inhabitants; $51.1 \%$ are women. ${ }^{3}$ In 1993 , the number of new BC cases registered was 5739 and $20 \%$ of them were residing in the state of Nuevo León. ${ }^{4}$ In 1998, yearly cases increased to $9490 .{ }^{4}$ The average BC mortality rate in Mexico is 10.45 /100 000 women. Nuevo Leon ranks third in mortality rate due to this cancer in the country, with 15.9/100 000 inhabitants, following by Mexico City and the state of Coahuila. The mortality rates due to BC are higher in the Northern states: Coahuila (16.1), Nuevo Leon, Sonora (14.5), Chihuahua (14.1), and Baja California (13.5). ${ }^{4}$

Increasing age is a major risk factor for $\mathrm{BC}$. The risk of developing the disease is 1 in 20000 for women younger than 25 years and this risk increases to 1 in 9 women older than 79 years. ${ }^{5}$ However, in 1998 in Mexico, ${ }^{4} 8 \%$ of all breast cancer cases presented in the early onset (EOBC) group (35 years of age or earlier at diagnosis). Many studies have demonstrated that BC in young patients has a more aggressive clinical course than in older patients. ${ }^{5}$ It is thought that tumors in younger women are biologically different, frequently with a higher proliferation index and less histological differentiation. In general, EOBC patients have shorter disease-free and reduced survival times. ${ }^{5}$

On the other hand, heredity is another important risk factor for $\mathrm{BC}$. It is estimated that it contributes 3 to $10 \%$ to BC cases and up to $30 \%$ to early onset ones. ${ }^{6}$ Mutations in BRCA1 and BRCA2 genes are responsible for $90 \%$ of the inherited BC cases. ${ }^{7}$

Since there is a lack of information in Mexico about the contribution of BRCA1 and BRCA2 genes to BC, the aim of this case series, prospective, hospital-based study of 22 Mexican women with EOBC was to describe the clinical course of $\mathrm{BC}$ and the presence of mutations of the BRCA1 and BRCA2 genes.

\section{Material and Methods}

Our protocol was reviewed and approved by the Scientific and Ethics Committee of the Hospital of Specialities \# 25, Mexican Institute of Social Security (IMSS). In our hospital an average of 250 new breast cancer cases are studied per year and 25 of them are women with EOBC. A sample of 22 consecutive women newly diagnosed with histologically confirmed EOBC, aged 35 years or younger at the time of diagno- sis, was recruited from the hospital in 1997. The study design and objectives were explained to the patients who were asked to sign an informed consent. The clinical histories were obtained and followed up for 5 years. Also, each patient donated $15 \mathrm{ml}$ of venous blood from which DNA was extracted. ${ }^{8}$ Mutations in the BRCA1 and BRCA2 genes were screened for by the heteroduplex analysis (HA). Variant bands observed in the HA were re-amplified and sequenced. ${ }^{9}$

Clinical and pathological data. Patients were interviewed by two of the authors (ALCG, PRF); a questionnaire was completed and patients' medical records were examined. Age at diagnosis and data about the clinical progress and outcome were also recorded. The tumor size was measured in centimeters at its largest diameter. All breast tumor slides were reviewed by one of the authors (ALCG). Tumors were classified histologically and recorded as ductal or lobular and subtypes of ductal carcinomas. ${ }^{10}$ The histological grade of differentiation of tumors was determined according to the modified Bloom-Richardson criteria. ${ }^{11}$ In the mastectomy specimen, the total numbers of lymph nodes, as well as the number of specimens with metastasis were recorded. The sites of metastasis were also described. Patients attended the hospital at least four times during the first year following diagnosis, and twice each subsequent year.

\section{Results}

Clinical characteristics. Table I shows the more important clinical and tumoral findings. The identification number (ID) of patients is given in Tables II and III. All patients accepted to participate in the study and none were lost during 1997-2002. The age range was 24 to 35 years; $68 \%$ of patients completed elementary school and $82 \%$ were housewives. History of BC in the family was present in six out of 22 cases (27\%) and two out of $22(9 \%)$ patients had a first degree relative with BC. Of the two women with truncated protein mutations (TPM), the one involving the BRCA1 gene had only a paternal aunt with $\mathrm{BC}$, while the other, who had the mutation in the BRCA2 gene, had a history of gastric and breast carcinoma in two paternal aunts; in the maternal line, she had two aunts with breast cancer, and one uncle with melanoma. Diabetes mellitus and arterial hypertension affected $9 \%$ of patients. Twenty patients had children (range 1-5) and the other two had not initiated active sexual life. Forty percent of patients with children breast-fed them. Eighty-six percent of patients did not smoke. According with the Bray classification, $36 \%$ of the patients had normal weight, $27 \%$ obesity grade I, $28 \%$ grade II, and $9 \%$ grade III. 
Table I

\section{Characteristics of patients With Early onset BREAST CANCER (1997- 2002). Hospital of Specialties \#25, Mexican Institute of Social Security}

\begin{tabular}{lcc} 
Characteristics & No. & $\%$ \\
A ge at diagnosis (years, median) & $32 \pm 3$ & $(24-35)$ \\
$\begin{array}{l}\text { Survival } \\
\text { Yes }\end{array}$ & & \\
\hline N 0 & 12 & $(54.55)$ \\
\hline $\begin{array}{l}\text { Clinical stage } \\
\text { IIA }\end{array}$ & 10 & $(45.45)$ \\
\hline IIB & & \\
\hline IIIA & 7 & $(31.82)$ \\
\hline & 8 & $(36.36)$ \\
\hline & 7 & $(31.82)$
\end{tabular}

Tumor size (cm, median) $5.20 \pm 1.56(2.5-8)$

\begin{tabular}{lrl}
$\begin{array}{l}\text { Histological type } \\
\text { Lobular }\end{array}$ & 1 & $(04.55)$ \\
\hline Ductal N 0 S* & 16 & $(72.73)$ \\
\hline Ductal comedo type & 3 & $(13.64)$ \\
\hline Ductal medullar type & 2 & $(09.09)$
\end{tabular}

Grade of tumor differentiation $n^{\ddagger}$

\begin{tabular}{lll} 
Moderate & 11 & $(52.38)$ \\
\hline Poor & 10 & $(47.61)$
\end{tabular}

Lymph node metastasis

\begin{tabular}{lll} 
Yes & 11 & $(50)$ \\
\hline No & 11 & $(50)$
\end{tabular}

Systemic metastasis sites

\begin{tabular}{lll}
$0=$ & 9 & $(40.91 \%)$ \\
\hline $1=$ & 5 & $(22.73 \%)$ \\
\hline Various $=$ & 8 & $(36.36 \%)$
\end{tabular}

* No otherwise specified

₹ Grade of tumor differentiation according to the modified RichardsonBloom classification for ductal carcinomas ${ }^{11}$

Tumor histology. Twenty-one tumors were classified as ductal carcinomas and the remaining one as lobular in origin (Table I). Ductal carcinomas were poorly and moderately differentiated in 10 out of 22 and 11 out of 22 cases, respectively. The two women with TPMs had a classical invasive lobular carcinoma (BRCA1 gene mutation) and a medullar carcinoma (BRCA2 gene mutation). The medullar carcinoma showed non-caseous granulomas distributed within the tumor and around

\section{Table II \\ Descriptions of the BRCA1 and BRCA2 gene mutations. Hospital of Specialties \#25, Mexican Institute of Social Security, 1997-2000}

\begin{tabular}{|c|c|c|c|c|c|}
\hline ID & $\begin{array}{l}\text { BRCA } \\
\text { gene }\end{array}$ & $\begin{array}{l}\text { Gene } \\
\text { site* }\end{array}$ & $\begin{array}{l}\text { Mutation } \\
\text { Type }^{\ddagger}\end{array}$ & $\begin{array}{l}\text { Mutation } \\
\text { Nature }\end{array}$ & $\begin{array}{l}\text { Protein } \\
\text { Effect\# }\end{array}$ \\
\hline 1 & 2 & 27 & $M S / P$ & A $10462 \mathrm{~T}$ & Ile3412Val \\
\hline 2 & 2 & 27 & $M S / P$ & $\mathrm{~A} 10462 \mathrm{~T}$ & Ile3412Val \\
\hline 3 & 2 & 27 & $M S / P$ & A 10462T & Ile3412Val \\
\hline 4 & 2 & 22 & $M S / P$ & G9079A & Ala2951Thr \\
\hline \multirow[t]{3}{*}{5} & 2 & 10 & $M S / P$ & A1093C & Asn289H is \\
\hline & 2 & 11 & $M S / P$ & A3199G & Asn991Asp \\
\hline & 2 & 22 & $M S / P$ & G9079A & Ala2951Thr \\
\hline 6 & 2 & 27 & P-silent & C9966T & Ala3246Ala \\
\hline \multirow[t]{3}{*}{7} & 1 & IVS7 & Intr-P & CIVS7-34T & Unknown \\
\hline & 2 & 10 & $\mathrm{Ms} / \mathrm{P}$ & A1093C & Asn289H is \\
\hline & 2 & 11 & $M S / P$ & A3199G & Asn991Asp \\
\hline \multirow[t]{3}{*}{8} & 1 & IVS7 & Intr-P & CIVS7-34T & Unknown \\
\hline & 2 & Intr 18 & Intr-P & $\mathrm{C} 8715+47 \mathrm{~T}$ & Unknown \\
\hline & 2 & 27 & $\mathrm{NS} / \mathrm{P}$ & A 10204T & Lys3326X \\
\hline 9 & 2 & 19 & MS/USM & G 8605A & Gly2793Arg \\
\hline 10 & 2 & 12 & MS/USM & T7105C & Phe2293Leu \\
\hline 11 & 2 & 27 & MS/USM & C 10349T & Thr3374lle \\
\hline \multirow[t]{2}{*}{12} & 1 & 11 & MS/USM & G2364T & Asp749Tyr \\
\hline & 2 & 27 & $M S / P$ & A 10462T & Ile3412Val \\
\hline 13 & 2 & 11 & FS & $2664 \operatorname{Ins} A$ & ter 826 \\
\hline$\overline{14}$ & 1 & 11 & FS & 3587delT & ter 1159 \\
\hline \multicolumn{6}{|c|}{$\begin{array}{l}\text { * Locus or intronic region } \\
\text { ₹ MS: missense mutation, N S: nonsense mutation, FS: frame shift mutation, } \\
\text { USM: uncertain significance mutation, P: polymorphism, intr: intron } \\
\text { \& A: adenine,T:thymine, C: citosine, G: guanine, del: deletion, Ins: insertion } \\
\text { \# ter: premature stop codon, lle: isoleucine, Val: valine, Asn: asparagine, } \\
\text { His: histidine,Asp: aspartate, Ala: alanine, Lys: lysine,Thr: threonine, Phe } \\
\text { phenylalanine, Leu: leucine, Gly: glycine,A Arg: arginine }\end{array}$} \\
\hline
\end{tabular}

its border. Special stains for fungi, tuberculosis bacilli, and bacteria were negative.

DNA data. Table II shows a description of the mutations found for the BRCA1 and BRCA2 genes. Only 14 of the 22 patients showed a variant band when the mutations in the BRCA1 and BRCA2 genes were screened by the heteroduplex analysis. Thus, $64 \%$ of patients with EOBC had variations in the DNA sequence involving BRCA1 or BRCA2 genes. The molecular findings were: 8 patients had one or more polymorphisms, 4 women had mutations of uncertain significance (USM) and 2 other had 2 novel TPM, one in BRCA1 (exon 11, 3587delT) and the other in BRCA2 gene (exon11, 2664InsA). In general, exclusively BRCA2 variant bands were found in $71.4 \%$ of the cases, versus only $7.14 \%$ of BRCA1 vari- 
ants; in $21.43 \%$, patients had both BRCA1 and BRCA2 variant bands. Polymorphisms were more frequently found in the BRCA2 gene, especially in exon 27, followed by exons 11,10 and 22 . The TPM affected exon 11 in BRCA1 and BRCA2 genes.

Table III shows the clinical stage and molecular findings in BRCA1 and BRCA2 genes and Table IV summarizes the molecular findings according with the clinical stage.

\section{Table III}

\section{Clinical evolution and molecular genetic findings. Hospital of Specialties \#25, Mexican Institute of Social Security, 1997-2000}

\begin{tabular}{|c|c|c|c|c|c|}
\hline & Age* & Alive & $\mathrm{CS}^{\ddagger}$ & DNA findings $s^{\S}$ & $\mathrm{T}^{\# / D G^{\&} \quad \text { M etastasis: site }}$ \\
\hline 1 & 30 & Yes & $\| A$ & BRCA2 polymorphism & D/M None \\
\hline 2 & 34 & Yes & $\| A$ & BRCA2 polymorphism & $\mathrm{D} / \mathrm{M}$ None \\
\hline 3 & 24 & Yes & $\| \mathrm{A}$ & BRCA2 polymorphism & $\mathrm{D} / \mathrm{M}$ Lungs \\
\hline 12 & 34 & Yes & $\| \mathrm{A}$ & BRCA1 USM & $\mathrm{D} / \mathrm{M}$ None \\
\hline 18 & 34 & Yes & $\| \mathrm{A}$ & normal & $\mathrm{D} / \mathrm{M}$ None \\
\hline 19 & 24 & No & $\| \mathrm{A}$ & normal & $\begin{array}{l}\text { D/M Lung, liver, bones, } \\
\text { lymph nodes }\end{array}$ \\
\hline 22 & 31 & Yes & $\| \mathrm{A}$ & normal & $\mathrm{D} / \mathrm{P}$ None \\
\hline 4 & 35 & Yes & $\| \mathrm{B}$ & BRCA2 polymorphism & $\mathrm{D} / \mathrm{M}$ None \\
\hline 9 & 30 & Yes & IIB & BRCA2 USM & D/P Ribs, lungs \\
\hline 10 & 33 & No & IIB & BRCA2 USM & $\begin{array}{l}\text { D/M Lumbar vertebral } \\
\text { bones }\end{array}$ \\
\hline 11 & 33 & No & IIB & BRCA2 USM & $\mathrm{D} / \mathrm{P}$ Lungs \\
\hline 13 & 32 & Yes & $\| B$ & BRCA2TPM & Med None \\
\hline 14 & 29 & Yes & IIB & BRCA1TPM & Lob None \\
\hline 16 & 34 & Yes & IIB & normal & D/P Liver \\
\hline 17 & 35 & No & $\| B$ & normal & $\begin{array}{ll}\mathrm{D} / \mathrm{P} & \text { Cerebellum, } \\
& \text { pleura, } \\
& \text { pericardium }\end{array}$ \\
\hline 5 & 33 & No & IIIA & BRCA2 polymorphism & D/P Liver \\
\hline 6 & 33 & No & IIIA & BRCA2 polymorphism & D/M Bones, skin \\
\hline 7 & 34 & Yes & IIIA & $\begin{array}{l}\text { BRCA2 polymorphism } \\
\text { BRCA1 polymorphism }\end{array}$ & $\mathrm{D} / \mathrm{M}$ None \\
\hline 8 & 34 & No & IIIA & $\begin{array}{l}\text { BRCA2 polymorphism } \\
\text { BRCA1 polymorphism }\end{array}$ & $\mathrm{D} / \mathrm{P} \quad$ Skull, liver \\
\hline$\overline{15}$ & 29 & No & IIIA & normal & $\begin{array}{l}\text { D/M Brain, kidneys, } \\
\text { liver }\end{array}$ \\
\hline 20 & 27 & No & IIIA & normal & D/M Bones \\
\hline 21 & 35 & No & IIIA & normal & D/P Brain, lungs, bones \\
\hline \multicolumn{6}{|c|}{ 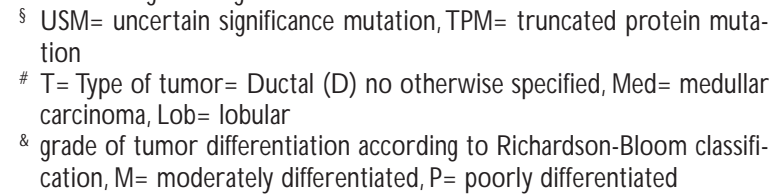 } \\
\hline
\end{tabular}

Table IV

\section{Clinical stage and number and type of molecular FINDINGS IN BRCA1 AND BRCA2 GENES. Hospital of Specialties \#25, Mexican Institute of Social Security, 1997-2000}

\begin{tabular}{lcccc} 
Clinical stage & $\begin{array}{c}\text { Dead } \\
\text { women/total }\end{array}$ & $\begin{array}{c}\text { Significant } \\
\text { mutation }\end{array}$ & USM $^{\text {a }}$ & Polymorphisms \\
IIA & $1 / 7$ & 0 & 1 & 3 \\
\hline IIB & $3 / 8$ & $2^{\text {b }}$ & 3 & 1 \\
\hline IIIA & $6 / 7$ & 0 & 0 & 4
\end{tabular}

a Uncertain significance mutation

${ }^{b}$ Frame shift type

All patients in the same clinical stage received the same treatment, including modified radical mastectomy, chemotherapy (5-fluoracile, epirubicine, cyclophosphamide) and radiotherapy. The five-year mortality among these women was about $45 \%$. Table IV shows the number of dead women/total with the clinical stage at diagnosis (1/7 in IIA, $3 / 8$ in IIB and 6/7 in IIIA). All deaths were caused by neoplastic activity and $80 \%$ occurred within the first 3 years following diagnosis. Fourteen patients developed metastatic disease, and among those, only 4 still remain alive.

\section{Discussion}

This follow-up study characterized 22 young women with $\mathrm{EOBC}$ who attended a tertiary care hospital in northeastern Mexico. Even though the results of this study cannot be extrapolated to the population at large, it provides useful information on which to base further studies.

Several risk factors particular to this group were observed. Obesity is a BC risk factor in postmenopausal women but apparently not in young women; ${ }^{12}$ nevertheless, 14 out of 22 of our women had some degree of obesity. The prevalence of family history of BC in our patients was similar to those previously reported among Mexican women ${ }^{13}$ and similar to American and European studies. ${ }^{14}$ The prevalence of common diseases such as diabetes mellitus and arterial hypertension was similar to that reported in adults in the north of Mexico. ${ }^{15}$

With one exception, all fatalities had lymph node metastases (LNM) at diagnosis. The sole exception initially underwent partial lymph node resection, with only six non-metastatic lymph nodes dissected after careful examination of axillary fat; later, developing 
ipsilateral LNM and systemic dissemination. On the other hand, two patients initially presenting with LNM survived, one of whom remained asymptomatic at the end of the study, and the other, who had a poorly differentiated neoplasm, developed liver metastasis and had terminal disease. These outcomes are consistent with those reported in the relevant literature. In general, metastatic involvement of axillary lymph nodes is one of the most important prognostic factors for survival in BC. Without LNM, 5-year survival is about $80 \%$, with one to three positive lymph nodes is $50 \%$ and only $21 \%$ with four or more nodes. ${ }^{16}$

In general, the frequency of mutations in BRCA1 and BRCA2 genes in our study sample seems to be very similar to that described in other studies of EOBC; ${ }^{17-19}$ however, some of this mutations had not been described before (the two PTM and gly2793Arg in BRCA2 gene and Asp749Tyr in BRCA1 gene) and this can be explained by the genetic characteristic of our mestizo population. ${ }^{20}$ If we consider only those mutations resulting in truncated proteins, BC in our patients was associated with mutations of BRCA1 and BRCA2 genes in $9 \%$ of cases, which is also consistent with the percentage of cases in the literature attributable to these types of mutations in these genes. ${ }^{17,18}$ Overall, depending on the population analyzed, the estimated percentage of mutations in young women with breast cancer is between 6 and $30 \%{ }^{19}$

As was mentioned before, the two truncating protein mutations detected in our Mexican women have not been reported previously in other countries. ${ }^{21}$ Since these women originated from northeastern Mexico, and had resided there for at least four generations, our observations may be identifying unique population mutations. In relation with the four cases with USM, further studies are needed to determine whether they correspond to clinically significant mutations or polymorphisms.

All the reported polymorphisms were in the BRCA2 gene, although some women also had them in the BRCA1 gene. It is well known that in different populations, the contribution of BRCA1 and BRCA2 genes may be different not only in polymorphisms but also in deleterious mutations; thus, in Jewish women, BRCA1 mutations are more frequent that BRCA2 ones, while in Italian women, the contribution of BRCA2 mutations predominates. ${ }^{22}$ The study of polymorphisms is important especially in a mestizo population, such as the Mexican case. Some of the polymorphisms described in these patients (CIVS7-34T in BRCA1 and A1093C in BRCA2 genes) have been previously described in Spain and elsewhere, ${ }^{21}$ including Africans $(\mathrm{C} 8715+47 \mathrm{~T}),{ }^{21}$ thus denoting the influence of these origins. $^{20}$
Early studies of women with mutations in BC susceptibility genes did not show differences between sporadic and mutation-associated tumors. ${ }^{23}$ More recent quantitative studies reveal higher nuclear grade, less positive expression to estrogen receptors, more pleomorphism and higher mitotic index in tumors associated with mutations than in sporadic tumors. ${ }^{24}$ One of our two cases had a lobular carcinoma (BRCA1 mutation) and the other a medullar carcinoma (BRCA2 mutation). Both of these histological tumor types have a better prognosis than the common ductal adenocarcinoma. Furthermore, the observation of non-caseous granulomas in the tumor probably signals active antitumor cellular immunity, and more importantly, these patients were among the survivors and are now clinically asymptomatic.

\section{Conclusions}

In summary, our study shows that breast cancer behaves aggressively in young Mexican women, particularly if the disease is clinically advanced at the time of diagnosis. ${ }^{16}$ We have also demonstrated the contribution of BRCA1 and BRCA2 genes in EOBC in Mexican patients. Although there are reports of mutations in Mexican-American women, ${ }^{25}$ this study is the first to describe both, the clinical progress and the molecular genetic analysis of BRCA1 and BRCA2 genes in Latin-American women. The two novel mutations were associated with less aggressive types of adenocarcinoma and non-metastatic, localized disease, in spite of a large tumor size. The ability to identify women with mutations allows further study of the family and, thus, early intervention, hopefully leading to a reduction in mortality. ${ }^{26}$

Our data point to the need for a large populationbased study to characterize the EOBC in Mexican women, in order to determine the type, frequency, and significance of variations in the sequences of BRCA1 and BRCA2 genes in Mexico.

\section{Acknowledgments}

To Professor RM Chandler- Burnst for his critical reading of our manuscript.

\section{References}

1. Pisani P, Parkin D M, Bray F, Ferlay J. Estimates of the worldwide mortality from cancer in 1990. Int J Cancer 1999;83(1):18-29. 2. Holford TR, Roush GC, MCK ay LA. Trends in female breast cancer in Connecticut and the United States. J Clin Epidemiol 1991;44(1):29-39. 3. Instituto $N$ acional de Estadística, G eografía e Informática. X II C enso General de Población y Vivienda 2000. A guascalientes, A guascalientes: 
IN EG I; 2001. D isponible en: http://www.inegi.gob.mx/est/contenidos/ españo//temáticos/mediano/anu.asp?t=mpob01

4. Secretaría de Salud. Compendio del Registro Histopatológico de N eoplasias en México. México, DF: SSA; 1998.

5. Henderson IC, Patek AJ.Are breast cancers in young women qualitatively distinct? Lancet 1997;349:1488-1489.

6. Tereschenko IV, Basham VM, Ponder BA, Pharoah PD. BRCA1 and

BRCA2 mutations in Russian familial breast cancer. Hum Mutat 2002;19(2):184

7. Antoniou AC, Pharoah PD, McMullan G, D ay N E, Stratton MR, Peto J et al.A comprehensive model for familial breast cancer incorporating BRCA1, BRCA2 and other genes. Br J Cancer 2002; 86 (1):76-83. 8. Miller SA, D ykes DD, Polesky HF.A simple salting out procedure for extracting DNA from human nucleated cells. N ucleic Acids Res 1988;16(3):1215.

9. Ruiz-Flores P, Sinilnikova O, Badzioch M, C alderón-G arcidueñas AL, Chopin S, Fabrice 0 et al. BRCA1 and BRCA2 mutation analysis of early-onset and familial breast cancer cases in Mexico. Hum Mutat 2002;20(6):474-475.

10. Cotran R, Kumar V, Robbins S.The breast. En: Schoen F, ed. Patología estructural y funcional. Fifth edition. Madrid: McG raw-Hill- Interamerican; 1998:1201-1222.

11. Frierson HF Jr,W olber RA, Berean KW, Franquemont DW, G affey MJ, Boyd JC et al. Interobserver reproducibility of the N ottingham modification of the Bloom-Richardson histological grading scheme for infiltrating ductal carcinoma. Am J C lin Pathol 1995;103(2):195-198. 12. C linton SK. D iet, anthropometry and breast cancer: Integration of experimental and epidemiologic approaches. J N utr 1997;127 Suppl 5:916S-920S

13. C alderón-G arcidueñas AL, Parás-Barrientos FU, C árdenas-Ibarra L, González-Guerrero JF,Villarreal-Ríos E, Staines-BooneT et al. Risk factors of breast cancer in Mexican women. Salud Publica Mex 2000;42(1):26-33.

14. Hoskins KF, Stopfer JE, Calzone KA, Merajver SD, RebbeckTR, $G$ arber JE et al.Assessment and counseling for women with a family history of breast cancer:A guide for clinicians. JAMA 1995;273: 577- 585.

15. Secretaría de Salud. Subsecretaría de Coordinación y D esarrollo. Encuestas $\mathrm{N}$ acionales de Salud: panorama de la salud en México. México, DF: SSA; 1994

16. Gompel C, Kerkem C. The breast. En: Silverberg S. Ed. Principles and practice of surgical pathology.Toronto:W iley Medical Publications; 1983:245-295.
17. De León-Matsuda ML, Liede A, Kwan E, Mapua CA, Cutiongco EM Tan A et al. BRCA1 and BRCA2 mutations among breast cancer patients from the Philippines. Int J Cancer 2002;98(4):596-603.

18. 0 sorio A, Barroso A, Martínez B, C ebrián A, San Román JM, Lobo $F$ et al. Molecular analysis of the BRCA1 and BRCA2 genes in 32 breast and/or ovarian cancer Spanish families. Br J Cancer 2000;82(7): 1266-1270.

19. Loman $\mathrm{N}$, Johannsson 0 , Kristoffersson U, O Isson H, Borg A. Family history of breast and ovarian cancers and BRCA1 and BRCA2 mutations in a population-based series of early-onset breast cancer. J $N$ atl C ancer Inst 2001;93(16):1188-1189.

20. Cerda-Flores RM,Villalobos-Torres MC, Barrera-Saldaña HA, Cortés-Prieto LM, Barajas LO, Rivas F et al. Genetic admixture in three Mexican mestizo populations based on D 1580 and HLA-DQA1 loci.Am J Hum Biol 2002;14(2):257-263.

21. An 0 pen Access 0 n-Line Breast $C$ ancer Mutation D ata Base.An International Collaborative Effort hosted by $\mathrm{N}$ ational Human Genetic Research Institute of the $\mathrm{N}$ ational Institute of $\mathrm{H}$ ealth.The Breast Cancer Information Core database design, structure, and scope. Disponible en: http://www.nhgri.nih.gov/bic/. [2001marzo 14]. 22. Krainer M, Silva-Arrieta S, FitzG erald MG, Shimada A, Ishioka C, Kanamaru $R$ et al. Differential contributions of BRC $A 1$ and BRCA2 to early-onset breast cancer. N Engl J Med 1997;336(20):1416-1421. 23. Marcus JN , W atson P, Page D L, Lynch HT. Pathology and heredity of breast cancer in younger women.J $\mathrm{N}$ atl $\mathrm{C}$ ancer Inst Monogr 1994;16:23-34.

24. Breast Cancer Linkage Consortium. Pathology of familial breast cancer: D ifferences between breast cancers in carriers of BRCA 1 or BRCA2 mutations and sporadic cases. Lancet 1997;349(9064):15051510.

25. D ejun S, Yanyuan W, Ram C, Jaydutt V.A truncated BRCA 1 gene mutation identified in a Hispanic-American breast cancer patient with a family history. Disponible en: www.medicineoftheamericas.org/ page_15.html. [2001 abril 3].

26. Burke W, Daly M, Garber J, Botkin J, Kahn MJ, Lynch P et al. Recommendations for follow-up care of individuals with an inherited predisposition to cancer. II. BRCA1 and BRCA2. C ancer Genetics Studies Consortium. JAMA 1997;277(12):997-1003. 